\title{
The three failures of creationism, by Walter M. Fitch
}

\author{
Alice B Kehoe
}

Keywords: Creationism; Logic of Science

The three failures of creationism, by Walter M. Fitch. 2012 University of California Press, Berkeley. ISBN 9780-520-27053-4 pbk. 194 pp., glossary, bibliography, index. $\$ 24.95$ (£16.95).

Walter Fitch was Professor of Ecology and Evolutionary Biology at the University of California-Irvine and a member of the National Academy of Sciences. Capping off a professional lifetime, he undertook to write a small textbook for high-school seniors and undergrads explaining problems with Creationist explanations contesting evolution. The result is useful to instructors, too, providing short, sound answers to questions about the alleged conflict between religion and science.

Logic, rhetoric, and science are the three areas where creationists fail, according to Fitch. He begins with a very basic introduction to logic, listing and giving examples of logical fallacies and of pitfalls such as "loaded words" like "methodological atheism" (used by creationist Philip Johnson), where "atheism" may be technically correct for science-by definition science does not postulate deities-but its connotation of expressed rejection of belief in deities is not involved (p. 21). His next chapter presents "The Basics," how we obtain knowledge from observation, authority, or faith. Theology, esthetics, ethics, and science are domains for judging and evaluating observations; Fitch explains how creationists fail to keep these domains separate, invoking theology to account for natural-world observations and ethics to claim moral worth as a criterion for accepting a scientific hypothesis. Fitch's next chapter lays out "some simple math and statistics" pertinent to the age of the earth and to genetics. This chapter requires more mental energy than the preceding ones, which could make it particularly educational for students, leading them through examples of mathematical thinking. The final chapter is called “'Young-Earth' Creationism”, although it could better be

Correspondence: akehoe@uwm.edu

Social and Cultural Sciences, Marquette University, Milwaukee WI 53201-1881, USA labeled "Creationist Arguments Rebutted." Here, Fitch tackles the common Creationist allegations one by one, concisely explaining their flaws in logic or in data. An epilogue quotes at length, St. Augustine's warning against Christians "talking nonsense" about scientific facts, "maintaining foolish opinions about the Scriptures." (Who knew the Bishop of Hippo combatted creationist dogma sixteen centuries ago?).

Because the book isn't written in narrative form, it may serve as a manual for teachers dealing with students and public wrongly told that science is at war with religion. That is Fitch's fundamental purpose, to clarify the two domains, science and religion, that a person may accept without conflict. By walking readers through a number of recognized logical fallacies, in Chapter One, Fitch teaches students that arguments are not just one fact against another. The chapter could well be used as a text in logic and rhetoric, with interesting examples of errors. Similarly, the chapter on "simple math and statistics" can stand as an introductory short text focusing on genetics. "The Basics" is somewhat different, with longer sections laying out parameters of the domains of theology, ethics, esthetics, and science, and concluding with showing how natural science does not point to either "progress" or moral implications.

In “'Young-Earth' Creationism”, Fitch begins with Biblical inerrancy, citing chapters in Genesis and Mesopotamian epics to demonstrate how the Old Testament is a compendium of diverse Near Eastern sources, resulting in disparate accounts in Genesis such as about creation of man and woman (p. 101). Creationists get around these discrepancies by selecting one or the other to be taught as the truth. Fitch's next section is on Noah's flood versus geological explanations of alleged proof of one universal flood. Here again, he suggests multiple Near Eastern sources for a common myth; he doesn't mention the possibility raised by a few archaeologists that melting of the massive continental Pleistocene glaciers resulted in such awesome floods that folk memories 
were passed down within myths. Fitch's next section in this chapter concerns Creationists' claims not based directly on the Bible, including how fossils originated (did God deliberately hoax scientists by planting skeletons stratigraphically?) and the Second Law of Thermodynamics (energy tends toward entropy, but-and he italicizes this: "Our planet itself is an open thermodynamic system") (p. 110). The Second Law specifies it pertains to closed systems. Fitch then moves on to "Intelligent Design," where his expertise in evolutionary genetics provides a clear explanation of how complex organs evolved, and some unusual examples, for instance the evolution of hemoglobin from single polypeptide chain in molluscs, marine worms, and certain nitrogen-fixing plants, through sea lampreys that are unique in having two chains, to most other animals that have four chains. A few are actually transitional from one to another form of hemoglobin (p. 121). Why would the Intelligent Designer leave incomplete models working along on earth? Aside from this question, Fitch patiently explains how allegedly perfectly designed complex systems were built up from earlier functioning parts, some of which, such as our appendixes, remain atavistically in organisms (pp. 112-114).

The final chapter also tells the reader that not all mutations are harmful, that it is foolish to suppose that earth was made for humans' benefit (the Anthropic Principle), that frauds such as the Piltdown hoax and ignorant assumptions such as the Paluxy River tracks being human and dinosaur living at the same time, are not proof that scientists are wrong, and that (pp. 142-144) teaching creationism and evolution as two, and the only two, competing models is not teaching science. This argument from Creationists, appealing to the notions of fair play and consumer choice, has been rejected in a series of legal decisions, the most recent being Kitzmiller v. Dover Area School District, 2005. Reading through this chapter and preceding pages, one is struck by the variety of antievolution arguments contrasted with the straightforward simplicity of evolution by natural selection. Fitch does warn against using esthetics to favor one explanation over another when the domain is science, not art, but here the beauty of Darwin's meticulously constructed model does shine.

In sum, Walter Fitch (1929-2011) cared deeply about understanding humans and our planet. $\mathrm{He}$ spent more than half a century judiciously investigating that through biology, using science to winnow information from speculation. At the conclusion of his career, he gave us this vade mecum for teachers of biology. One of its strengths is its broad approach from logic and rhetoric. We can see that Professor Fitch was grounded in humanities as well as science, a good point to make to students.

Review by Alice B. Kehoe

Professor of Anthropology, emeritus, Marquette University (USA).

\section{Competing interests}

The author declares that she has no competing interests.

Received: 30 March 2014 Accepted: 6 June 2014 Published online: 03 July 2014

doi:10.1186/s12052-014-0017-0

Cite this article as: Kehoe: The three failures of creationism, by Walter $\mathrm{M}$.

Fitch. Evolution: Education and Outreach 2014 7:17.

\section{Submit your manuscript to a SpringerOpen ${ }^{\circ}$ journal and benefit from:}

- Convenient online submission

$\checkmark$ Rigorous peer review

- Immediate publication on acceptance

- Open access: articles freely available online

- High visibility within the field

- Retaining the copyright to your article

Submit your next manuscript at $\boldsymbol{\triangleright}$ springeropen.com 